\title{
Review
}

\section{p40: A p63 Isoform Useful for Lung Cancer Diagnosis - A Review of the Physiological and Pathological Role of p63}

\author{
Ana Rita Nobre ${ }^{a, b}$ André Albergaria ${ }^{a, c}$ Fernando Schmitt ${ }^{a, c}$ \\ ${ }^{a}$ Cancer Genetics Group, Institute of Molecular Pathology and Immunology of Porto University (IPATIMUP), \\ ${ }^{b}$ Institute of Biomedical Sciences of Abel Salazar (ICBAS), and ' Department of Pathology, Medical Faculty of \\ Porto University, Porto, Portugal
}

\section{Key Words}

p63 $\cdot$ p40 $\cdot$ Lung cancer $\cdot$ Squamous cell carcinoma

\begin{abstract}
At present, p63, TTF-1, and Napsin-A are the main immunochemical markers used to distinguish squamous cell carcinoma (SCC) from lung adenocarcinoma (ADC). However, studies using antibodies against p63 have demonstrated false-positive results with positivity in some ADC. In contrast, the expression of one of the p63 isoforms ( $\Delta$ Np63), detected by the antibody p40, is highly specific for SCC. Since most cases of lung cancer are diagnosed in small specimens (cytology/biopsies) and saving material for molecular analysis is mandatory, we recommended the use of p40 (in adjunct with TTF-1 and/or Napsin-A) as the best approach to discriminate SCC and lung ADC. In this paper, we review the physiological and pathological role of p63 isoforms as well as their use as diagnostic markers in lung SCC.
\end{abstract}

Copyright ๑ 2012 S. Karger AG, Basel

\section{Introduction}

The p63 gene, located on chromosome 3q27-29, contains 15 exons and exhibits a remarkable sequence and structural homology with p53. Like p53, the p63 gene encodes an N-terminal transactivation domain, a core DNA binding domain, and a carboxy-oligomerization domain. Furthermore, p63 shares all of the hotspots for p53 mutations in human tumors $[1,2]$. TP53 has a single promoter but encodes the full-length p53 and a splice variant, $\Delta \mathrm{Np} 53$ [3]. In contrast, TP63 has two promoters, producing two opposing classes of proteins by alternative splicing, one containing the transactivation domain (TAp63) and the other lacking it $(\Delta \mathrm{Np} 63)$. An additional complexity is generated at the $\mathrm{COOH}$ terminus, where splicing of exons leads to 5 different C-termini $(\alpha, \beta, \gamma, \delta$, or $\varepsilon)$ [4]. The $\Delta \mathrm{N}$ isoforms of $\mathrm{p} 63$ were initially described as unable to induce transcription, acting in a dominant negative manner either by competing for DNA binding sites or by directly binding to p53 or TA isoforms, rendering them inactive. However, more recently it has been suggested that $\Delta$ Np63 have important transcriptional activities on their own $[1,5]$. Zebrafish embryos require $\Delta N p 63$ to inhibit p53 and thus allow epidermal proliferation and limb development [6]. On the other hand, under stress condi-

\section{KARGER}

Fax +4161306 1234

E-Mail karger@karger.ch

www.karger.com
2012 S. Karger AG, Basel

0001-5547/13/0571-0001\$38.00/0

Accessible online at:

www.karger.com/acy
Correspondence to: Prof. Dr. Fernando Schmit

Institute of Molecular Pathology and Immunology of Porto University

Rua Dr. Roberto Frias s/n

PT-4200-465 Porto (Portugal)

E-Mail fschmitt@ipatimup.pt 
tions, such as UV-B irradiation, $\Delta \mathrm{Np} 63 \alpha$ has been shown to be downregulated to allow $\mathrm{p} 53$ and TA isoforms to induce apoptosis [7]. TA isoforms can bind to p53-consensus sequences and induce p53-target genes, with TAp $63 \alpha$ being the weakest transcription activator [1], while TAp63 $\gamma$ is able to induce cell cycle arrest and apoptosis [8].

Reinforcing this connection between p63 and the stratified squamous phenotype, another model of mice which expressed p63 in a single-layered lung epithelium showed a shift to stratified squamous epithelium [9]. In contrast, a zebrafish model with specific disruption of $\Delta$ Np63 resulted in lack of epidermal morphogenesis and fin truncations $[6,10]$.

The purpose of the present study is to discuss the expression of p63 in normal and tumor tissues with a special focus on the diagnostic value of $\mathrm{p} 40(\Delta \mathrm{Np} 63 \alpha)$ in lung squamous cell carcinoma (SCC).

\section{p63 Expression in Normal Tissue}

p63 is consistently expressed in specific cells, tissues, and developmental/differentiation timings. In embryonic epidermis, p63 is the molecular switch for initiation of an epithelial stratification program [9], and in postnatal epidermis p63 expression is restricted to the nuclei of basal cells of normal epithelia, such as skin, esophagus, tonsil, urothelium, ectocervix and vagina, and basal cells of glandular structures of prostate, breast, and bronchi [1, 11]. Importantly, these cells predominantly express the $\Delta$ Np63 isotype in about 100 -fold to TAp63 [1]. This basal compartment of stratified epithelia, which lies directly on the basement membrane, is considered to harbor cells with a high proliferative capacity, which is in agreement with the hypothesis that p63 is required for the maintenance or differentiation of progenitor cell populations necessary for epithelia development. In stratified epithelia, p63 is expressed in the basal cell layer but staining extends only about halfway up through the epithelium. Fewer cells in the basal layers are positive for TAp63, but positive staining is seen higher up in the epithelium when compared with $\Delta \mathrm{Np} 63$ expression. In stratified squamous epithelia, while basal cells express $\Delta \mathrm{Np} 63 \alpha$ and cells higher up in the epithelium express TAp63 $\alpha$, intermediate cells express both p63 $\alpha$ isoforms [12]. In glandular epithelia such as breast and prostate, p63 display an intense nuclear staining in basal cells whereas the luminal cells lining the glandular lumen are unreactive $[11,13$, 14]. Regarding p63 isoforms, expression of $\Delta \mathrm{Np} 63 \alpha$ is no- ticeable in the nuclei of cells in the basal layers of the normal breast and prostate epithelium, and in occasional suprabasal cells, and no staining is seen in luminal epithelial glandular cells [12]. By double staining for cytokeratin, some of the $\Delta \mathrm{Np} 63$-positive cells are shown to be breast myoepithelial cells or basal epithelial cells in the prostate. In contrast, TAp63 proteins are present in most of the epithelial lining cells, including secretory epithelial cells, but they are absent in the myoepithelial and basal cells [12]. Several skin adnexa as sebaceous and sweat glands also show an intense and specific expression of p63 in their basal cell compartments. A similar pattern is observed in the basal cells of the bronchial tree [11].

Although TAp63 and $\Delta$ Np63 show overlapping distributions in some epithelial tissues, TAp63 is less expressed in basal cells and more expressed in differentiated cells, which implies that single expression of $\Delta \mathrm{Np} 63 \alpha$ is seen in the stem-like cell populations, while single expression of TAp $63 \alpha$ correlates with the fully differentiated phenotype. These distinct p63 isoform patterns suggest that changes in the expression of these p63 isoforms may contribute significantly to biological processes such as proliferation and differentiation of epithelia.

\section{p63 in Human Disease}

\section{p63 in Human Developmental Syndromes}

Several syndromes in humans have phenotypes that are reminiscent of the p63 knockout mouse, but in contrast to the murine p63-null model, which lacks ectodermal stratification, as well as, lachrymal, salivary, and mammary gland development $[15,16]$, the human syndromes display a range of less profound defects. Nonetheless, these abnormalities are reflected in the same target epithelium or tissues and there are 6 rare autosomal dominant developmental disorders associated with $p 63$ mutations, i.e ectrodactyly ectodermal dysplasia clefting (EEC), ankyloblepharon ectodermal dysplasia clefting (AEC or Hay-Wells), acro-dermato-ungual-lacrimaltooth syndrome (ADULT), limb mammary syndrome (LMS), Rapp-Hodgkin syndrome, and split-hand/foot malformations $[17,18]$. It has been shown that heterozygous mutations in the $p 63$ gene are associated with these diseases with a clear genotype-phenotype correlation. However, these patients do not frequently develop tumors $[17,18]$, which is in striking contrast to the heterozygous mutations in p53 (Li-Fraumeni syndrome), which almost inevitably lead to carcinogenesis. Interestingly, the diverse range of mutations suggests many different mecha- 
Fig. 1. Schematic drawing of $\Delta \mathrm{Np} 63$ expression in mechanisms of squamous differentiation. $\Delta \mathrm{Np} 63$ is hypothesized to sustain stem cell populations after asymmetric division of a stem cell into one daughter cell programmed for differentiation. The other cell retains the undifferentiated progenitor-stem cell proliferative phenotype. Furthermore, loss of $\Delta \mathrm{Np} 63$ is essential to the commitment of undifferentiated dividing cells to undergo maturation, so when cells maintain the $\Delta \mathrm{Np} 63$ expression, and the functional predominance over TAp63 isoforms, $\Delta \mathrm{Np} 63 \mathrm{might}$ prevent activation of division-suppressive pathways triggered by p53 or full-length TAp63. This mechanism keeps cells in a differentiation-resistant stem cell-like state and induces squamous cell differentiation.

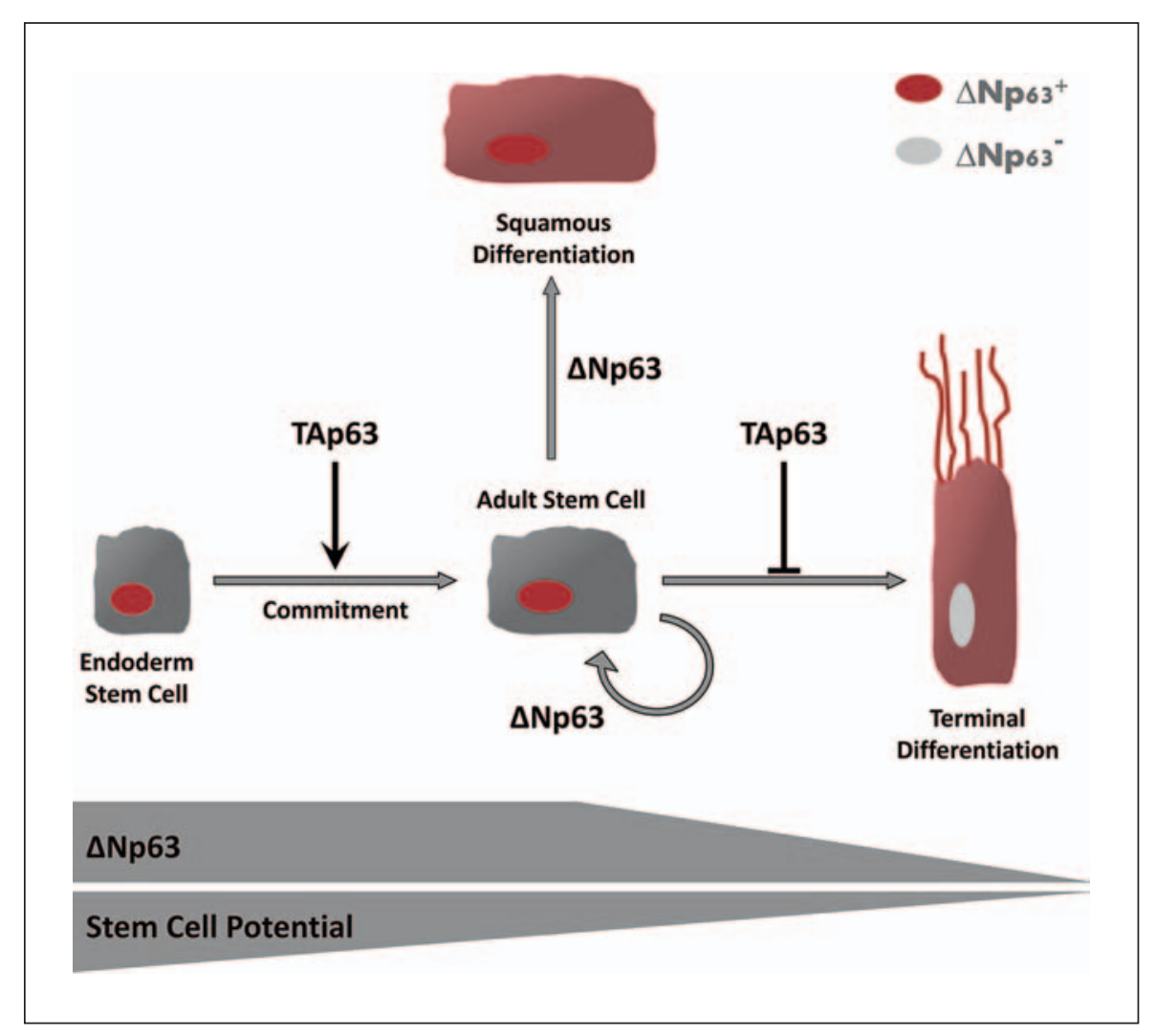

nisms for altering p63 function. Even though p63 is rarely mutated in human tumors, which makes a tumor suppressor function unlikely, amplification of the p63 gene and elevated expression of $\Delta \mathrm{N}$ isoforms has been found in several carcinomas, indicating an oncogenic role of these isoforms [19-23].

\section{p63 in Cancer}

The structural similarity between p63 and p53 led to the early hypothesis that p63 would likewise be a tumor suppressor and a sensor of DNA damage. Indeed, some studies have shown that p63 can induce apoptosis, being upregulated in cells that have been treated with DNA damaging agents $[1,24]$, and that the knockdown of p63 leads to a loss of cell adhesion, cellular arrest, invasion, and metastasis, which are important steps in tumor progression [25-27]. It was also suggested that p63 is required for myoepithelial cell differentiation and that the elimination of it results in loss of myoepithelial cells and progression to invasion [27]. Taken together, these studies indicate that loss of p63 can lead to tumor progression, but this does not exclude the possibility that p63 can also act as an oncogene, as has been suggested by other find- ings. The $p 63$ gene is very rarely mutated in human tumors or cancer cell lines $[8,28]$ and no loss of heterozygosity occurs at the p63 locus in cancer. However, the $3 q 27-29$ region containing the $p 63$ gene is frequently amplified in many human malignancies [20,23].

In fact, p63 has been shown to be overexpressed in many tumors, especially in squamous cell lung carcinoma (SCC) of the head and neck (HNSCC), lung [22], skin [29], and cervix [30, 31]. Many of them actually overexpress the $\Delta$ Np63 isoforms, while TAp63 expression is lost $[19,20,32]$.

SCC, but not adenocarcinomas (ADC), frequently show an amplified p63 locus, 3q27-28, [20, 23, 33, 34], and some lung cancers and HNSCC show p63 overexpression associated with a modest increase in TP63 copy numbers [20]. Importantly, the majority of the p63 amplified isoforms in SCC are dominant-negative $\Delta \mathrm{Np} 63$ forms which act like an oncogene in nude mice [20].

In HNSCC and in cervical carcinomas, strong p $63 \alpha$ and $\Delta \mathrm{Np} 63$ expression is seen in tumor cells distributed throughout the tumors, with $\Delta \mathrm{Np} 63 \alpha$ being the predominant isoform overexpressed in these tumors compared to matched normal tissue specimens [12]. Similar pre- 

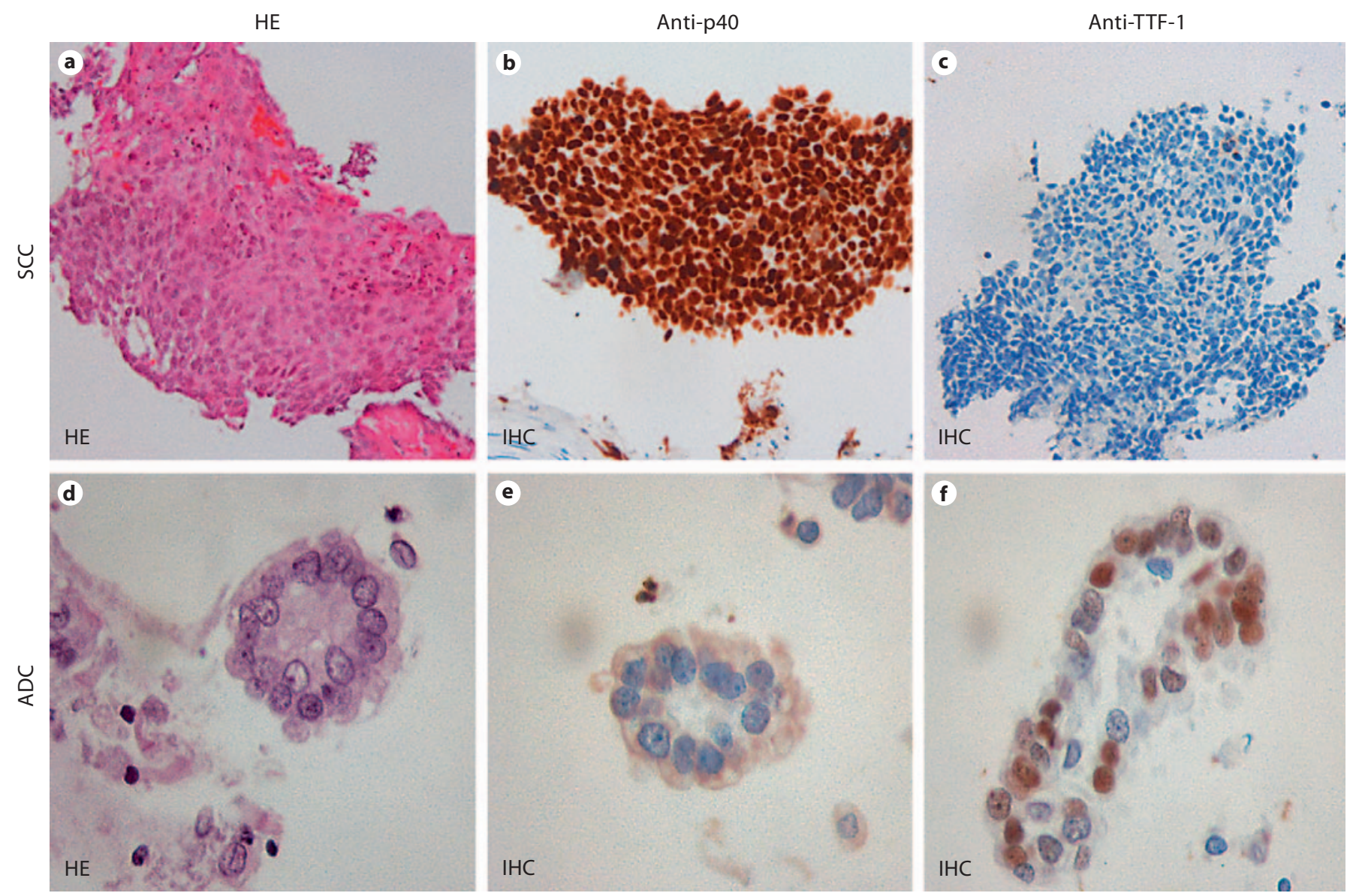

Fig. 2. p40 and TTF-1 immunoexpression in lung cancer. Cell blocks obtained from poorly differentiated SCC $(\mathbf{a}-\mathbf{c})$ and ADC (d-f). The SCC shows strong nucleus positivity for p40 (b) and negativity for TTF-1 (c) while the ADC has the opposite p40 (e) and TTF-1 (f) immunoexpression. HE = Hematoxylin and eosin stain.

dominant overexpression of $\Delta \mathrm{Np} 63$ is also found in esophageal SCC, in contrast to normal esophagus where p63 staining is restricted to the proliferating basal and suprabasal cell layers $[35,36]$. These findings have supported that $\Delta$ Np63 plays an anti-differentiation and antiapoptotic role, a key role in the tumorigenesis, but also that these isoforms contribute to keep a stem-like phenotype in SCC (fig. 1).

In epithelial tumors with p63 restricted to the basal cell population, $\Delta \mathrm{Np} 63 \alpha$ is also frequently undetectable. Examples of that are breast, prostate, and cutaneous lesions, such as basal cell carcinoma, basal cell nevus syndrome, and nevus sebaceous, which strongly express p63 in normal cells of the basal layer but not in carcinomas $[11,37]$. In prostate, p63 staining is restricted to the basal cell layer, being a reliable marker of basal cells; however, the vast majority of prostate cancers and pre-invasive prostate intraepithelial neoplasia lesions lose p63 expression, making it an excellent diagnostic marker in prostate cancer which can be used clinically for differential diagnosis [38-40]. Similarly, p63 is also a marker of myoepithelial cells of breast ducts [13] but it is expressed only in a few cases of breast of carcinoma.

\section{p63 in Lung Cancer}

The fight against lung cancer is greatly compromised by the lack of effective early detection strategies. Genomic abnormalities, and specifically the amplification of chromosomal region 3q26-3qter, represent a major signature of neoplastic transformation in lung cancer [20, 23, 41]. Interestingly, the $p 63$ genomic sequence maps in this amplicon (3q27-29) [1, 2, 4].

In normal lung, p63 is expressed at the basal layer of the airway epithelium, a layer that has high regenerative 
Table 1. Distribution of TTF-1, p63, and p40 in lung cancer

\begin{tabular}{|c|c|c|c|c|c|c|c|c|c|c|}
\hline & \multicolumn{5}{|c|}{ Histological diagnosis } & \multirow[t]{2}{*}{ SE } & \multirow[t]{2}{*}{ SP } & \multirow[t]{2}{*}{ PPV } & \multirow[t]{2}{*}{ NPV } & \multirow[t]{2}{*}{ Ref. } \\
\hline & $\mathrm{ADC}$ & SCC & LCC/SC & ADSC & LCL & & & & & \\
\hline p63 & $27 / 150(18)$ & $50 / 50(100)$ & n.a. & n.a. & n.a. & 1.00 & 0.82 & 0.65 & 1.00 & \\
\hline $\mathrm{p} 40$ & $0 / 150(0)$ & $50 / 50(100)$ & n.a. & n.a. & n.a. & 1.00 & 1.00 & 1.00 & 1.00 & \\
\hline TTF-1+/p63+ & $26 / 180(14)$ & $0 / 50(0)$ & n.a. & n.a. & n.a. & 0.14 & 1.00 & 1.00 & 0.25 & \\
\hline TTF-1-/p63- & $35 / 180(19)$ & $0 / 50(100)$ & n.a. & n.a. & n.a. & 0.19 & 1.00 & 1.00 & 0.26 & \\
\hline TTF-1+/p40+ & $0 / 180(0)$ & $0 / 50(0)$ & n.a. & n.a. & n.a. & 0.00 & 1.00 & 0.00 & 0.22 & \\
\hline TTF-1+/p40- & $141 / 180(78)$ & $0 / 50(0)$ & n.a. & n.a. & n.a. & 0.78 & 1.00 & 1.00 & 0.56 & \\
\hline TTF-1-/p40+ & $0 / 180(0)$ & $50 / 50(100)$ & n.a. & n.a. & n.a. & 1.00 & 1.00 & 1.00 & 1.00 & \\
\hline TTF-1-/p40- & $39 / 180(22)$ & $0 / 50(0)$ & n.a. & n.a. & n.a. & 0.00 & 0.78 & 0.00 & 0.74 & \\
\hline TTF-1+/p63- & $20 / 30(67)$ & $0 / 10(0)$ & $0 / 1(0)$ & $0 / 5(0)$ & n.a. & 0.67 & 1.00 & 1.00 & 0.50 & \\
\hline TTF-1-/p63+ & $1 / 30(3)$ & $10 / 10(100)$ & $1 / 1(100)$ & $2 / 5(40)$ & n.a. & 1.00 & 0.97 & 0.91 & 1.00 & \\
\hline TTF-1-/p63- & $1 / 30(3)$ & $0 / 10(0)$ & $0 / 1(0)$ & $0 / 5(0)$ & n.a. & 0.00 & 0.97 & 0.00 & 0.74 & \\
\hline TTF- $1+/ \mathrm{p} 40+$ & $4 / 30(14)$ & $0 / 10(0)$ & $0 / 1(0)$ & $3 / 5(60)$ & n.a. & 0.13 & 1.00 & 1.00 & 0.28 & \\
\hline TTF-1+/p40- & $24 / 30(80)$ & $0 / 10(0)$ & $0 / 1(0)$ & $0 / 5(0)$ & n.a. & 0.80 & 1.00 & 1.00 & 0.63 & \\
\hline TTF-1-/p40+ & $1 / 30(3)$ & $10 / 10(100)$ & $0 / 1(0)$ & $2 / 5(40)$ & n.a. & 0.53 & 0.97 & 0.91 & 0.76 & \\
\hline TTF-1-/p40- & $1 / 30(3)$ & $0 / 10(0)$ & $1 / 1(100)$ & $0 / 5(0)$ & n.a. & 0.00 & 0.97 & 0.00 & 0.74 & \\
\hline p63 & $74 / 237(31)$ & $81 / 81(100)$ & n.a. & n.a. & $82 / 152(54)$ & 1.00 & 0.69 & 0.52 & 1.00 & 47 \\
\hline $\mathrm{p} 40$ & $7 / 205(3)$ & $81 / 81(100)$ & n.a. & n.a. & $0 / 152(0)$ & 1.00 & 0.97 & 0.92 & 1.00 & \\
\hline TTF-1 & $51 / 66(77)$ & $0 / 24$ & $3 / 12$ & $0 / 1$ & n.a. & 0.77 & 1.00 & 1.00 & 0.62 & 49 \\
\hline
\end{tabular}

Integrative data of the expression of TTF-1, p63, and p40 in subtypes of lung cancer and comparison of the sensibility and specificity of these markers for SCC. Values in parentheses are percentages. ADSC = Adenosquamous carcinoma; LCC = large cell carcinoma; $\mathrm{LCL}=$ large cell lymphoma; n.a. = not assessed; NPV = negative predictive value; $\mathrm{PPV}=$ positive predictive value; $\mathrm{SC}=$ sarcomatoid carcinoma; $\mathrm{SE}=$ sensitivity; $\mathrm{SP}=$ specificity; Ref. $=$ reference.

potential $[1,20,42]$. Nuclei of bronchial reserve cells intensely express p63 while ciliated cells, alveolar epithelial cells, and nonepithelial cells do not express p63. In the neoplastic context, SCC expresses p63 whereas ADC and small cell carcinomas are almost all negative for p63 [43].

It is therapeutically relevant to distinguishing between lung ADC and SCC in relation to treatment decisions and the differential activity of specific therapeutic agents. Histological subdivision between the two is generally not difficult but poorly differentiated tumors can be doubtful even in experienced hands.

p63 amplification occurs early in the development of lung cancer and may have important implications in ear- ly detection strategies [23, 41]. Although some authors claim that p63 immunostaining may be an aid for a panel of immunohistochemistry (IHC) stains [43], poorly differentiated carcinomas show high proportions of p63positive nuclei and a progressive increase in $\mathrm{p} 63$ expression is observed throughout the depth of the epithelium from metaplasia to severe dysplasia. Moreover, the p63 immunoreaction increases progressively from pre-neoplastic and pre-invasive lesions to invasive SCC $[42,44]$. Consistent with that, in SCC, but not in ADC, p63 immunoreactivity correlated directly with the tumor proliferative fraction and inversely with the tumor grade [42]. Thus, p63 may be an important player during the devel- 
opment and transformation of pulmonary squamous epithelia but it does not offer a major advantage in terms of pathological distinction and prognostic implications for non-small cell lung cancer (NSCLC) patients. In fact, patients with NSCLC showing 3q amplification and overexpression of p63 have prolonged survival [23]. Indeed, p63 amplification and overexpression of $\Delta \mathrm{Np} 63 \alpha$ are critical steps in the early development of NSCLC and may prove to be a good biomarker of squamous carcinoma progression. Moreover, $3 \mathrm{q}$ amplification occurs in the majority of SCC and rarely in ADC, and it is present in lesions exhibiting severe dysplasia and in more advanced stages of tumor progression $[1,20]$.

Although $\Delta$ Np63 and TAp63 splice variants are expressed in NSCLCs, $\triangle \mathrm{Np} 63 \alpha$ is the predominant isoform, and in contrast to TAp63 it is selectively expressed in SCC $[45,46]$. Moreover, $\Delta \mathrm{Np} 63 \alpha$ immunoexpression is associated with better survival independent of the stage and degree of differentiation of the tumor, and it has been shown in several distinct studies that the use of $\Delta \mathrm{Np} 63 \alpha$ expression using the antibody $\mathrm{p} 40$ instead of detection of p63 using the 4A4 antibody prevents the misinterpretation of p63-positive poorly differentiated ADC or unsuspected lymphoma as SCC. Comparing the immunostaining of standard p63 antibody (4A4) with p40 it was observed that all lung SCC were positive for p63, but only a few ADC and large cell lymphomas were also positive, while $\mathrm{p} 40$ was positive in all SCC but only in a few ADC. Moreover, it is well documented that TTF-1 can rarely show focal reactivity in SCC, being a good adjunct to $\mathrm{p} 40$ to discriminate ADC and SCC. Furthermore, $100 \%$ sensitivity and $83-100 \%$ specificity were reached by different groups (fig. 2; table 1) [45-49].

p40 IHC has emerged as an easy, quick, and inexpensive technique with high sensitivity and specificity to distinguish lung ADC and SCC and appears to be an excel- lent marker for SCC. In conclusion, p40 immunostaining should be performed routinely for the diagnosis of pulmonary SCC.

\section{Conclusion}

Currently, lung tumors are histologically subdivided based on morphology, and when surgical samples are available specific histotypes are assessed; however, it is necessary to improve lung tumor subtyping. Several studies have been conducted to evaluate approaches to effectively forecast this 'surgical specimen profiling' and determine the best way to save time, financial resources, and diagnostic material. Cytology/biopsy samples and IHC are worthwhile techniques to assess this profiling and $\mathrm{p} 40$ antibody promises to be a valuable biomarker to refine the subtyping by cytology or biopsy samples, particularly with regard to ADC and SCC [46, 49]. Moreover, we recommend the use of p40 immunostaining rather than p63, which would raise novel clinical lung cancer perspectives, especially in poorly differentiated lung cancer, which are often associated with shorter survival and more advanced stage [50, 51].

\section{Acknowledgments}

IPATIMUP is an Associate Laboratory of the Portuguese Ministry of Science, Technology, and Higher Education and is partially supported by FCT.

\section{Disclosure Statement}

The authors have no conflicts of interest to declare.

\section{References}

1 Yang A, Kaghad M, Wang Y, Gillett E, Fleming MD, Dotsch V, Andrews NC, Caput D, McKeon F: p63, a p53 homolog at 3q27-29, encodes multiple products with transactivating, death-inducing, and dominant-negative activities. Mol Cell 1998;2:305-316.

2 Schmale H, Bamberger C: A novel protein with strong homology to the tumor suppressor p53. Oncogene 1997;15:1363-1367.
3 Courtois S, Verhaegh G, North S, Luciani MG, Lassus P, Hibner U, Oren M, Hainaut P: DeltaN-p53, a natural isoform of p53 lacking the first transactivation domain, counteracts growth suppression by wild-type p53. Oncogene 2002;21:6722-6728.

4 Westfall MD, Pietenpol JA: p63: molecular complexity in development and cancer. Carcinogenesis 2004;25:857-864.

5 McKeon F: p63 and the epithelial stem cell: more than status quo? Genes Dev 2004;18: 465-469.
6 Lee H, Kimelman D: A dominant-negative form of $\mathrm{p} 63$ is required for epidermal proliferation in zebrafish. Dev Cell 2002;2:607616.

-7 Liefer KM, Koster MI, Wang XJ, Yang A, McKeon F, Roop DR: Down-regulation of p63 is required for epidermal UV-B-induced apoptosis. Cancer Res 2000;60:4016-4020. 
-8 Osada M, Ohba M, Kawahara C, Ishioka C, Kanamaru R, Katoh I, Ikawa Y, Nimura Y, Nakagawara A, Obinata M, Ikawa S: Cloning and functional analysis of human p51, which structurally and functionally resembles $\mathrm{p} 53$. Nat Med 1998;4:839-843.

-9 Koster MI, Kim S, Mills AA, DeMayo FJ, Roop DR: p63 is the molecular switch for initiation of an epithelial stratification program. Genes Dev 2004;18:126-131.

-10 Bakkers J, Hild M, Kramer C, Furutani-Seiki M, Hammerschmidt M: Zebrafish deltaNp63 is a direct target of bmp signaling and encodes a transcriptional repressor blocking neural specification in the ventral ectoderm. Dev Cell 2002;2:617-627.

-11 Di Como CJ, Urist MJ, Babayan I, Drobnjak M, Hedvat CV, Teruya-Feldstein J, Pohar K, Hoos A, Cordon-Cardo C: p63 expression profiles in human normal and tumor tissues. Clin Cancer Res 2002;8:494-501.

-12 Nylander K, Vojtesek B, Nenutil R, Lindgren B, Roos G, Zhanxiang W, Sjostrom B, Dahlqvist A, Coates PJ: Differential expression of p63 isoforms in normal tissues and neoplastic cells. J Pathol 2002;198:417-427.

$\checkmark 13$ Reis-Filho JS, Milanezi F, Amendoeira I, Albergaria A, Schmitt FC: Distribution of p63, a novel myoepithelial marker, in fine-needle aspiration biopsies of the breast: an analysis of 82 samples. Cancer 2003;99:172-179.

$\checkmark 14$ Reis-Filho JS, Milanezi F, Amendoeira I, Albergaria A, Schmitt FC: p63 staining of myoepithelial cells in breast fine needle aspirates: a study of its role in differentiating in situ from invasive ductal carcinomas of the breast. J Clin Pathol 2002;55:936-939.

- 15 Yang A, Schweitzer R, Sun D, Kaghad M, Walker N, Bronson RT, Tabin C, Sharpe A, Caput D, Crum C, McKeon F: p63 is essential for regenerative proliferation in limb, craniofacial and epithelial development. Nature 1999;398:714-718.

- 16 Mills AA, Zheng B, Wang XJ, Vogel H, Roop $\mathrm{DR}$, Bradley A: p63 is a p53 homologue required for limb and epidermal morphogenesis. Nature 1999;398:708-713.

$\checkmark 17$ Crum CP, McKeon FD: p63 in epithelial survival, germ cell surveillance, and neoplasia. Annu Rev Pathol 2010;5:349-371.

18 Rinne T, Brunner HG, van Bokhoven H: p63-associated disorders. Cell Cycle 2007;6: 262-268.

-19 Crook T, Nicholls JM, Brooks L, O'Nions J, Allday MJ: High level expression of deltaN-p63: a mechanism for the inactivation of p53 in undifferentiated nasopharyngeal carcinoma (NPC)? Oncogene 2000;19:34393444.

20 Hibi K, Trink B, Patturajan M, Westra WH, Caballero OL, Hill DE, Ratovitski EA, Jen J, Sidransky D: AIS is an oncogene amplified in squamous cell carcinoma. Proc Natl Acad Sci USA 2000;97:5462-5467.
21 Park BJ, Lee SJ, Kim JI, Lee CH, Chang SG, Park JH, Chi SG: Frequent alteration of p63 expression in human primary bladder carcinomas. Cancer Res 2000;60:3370-3374.

-22 Yamaguchi K, Wu L, Caballero OL, Hibi K, Trink B, Resto V, Cairns P, Okami K, Koch WM, Sidransky D, Jen J: Frequent gain of the $\mathrm{p} 40 / \mathrm{p} 51 / \mathrm{p} 63$ gene locus in primary head and neck squamous cell carcinoma. Int J Cancer 2000;86:684-689.

23 Massion PP, Taflan PM, Jamshedur Rahman SM, Yildiz P, Shyr Y, Edgerton ME, Westfall MD, Roberts JR, Pietenpol JA, Carbone DP, Gonzalez AL: Significance of p63 amplification and overexpression in lung cancer development and prognosis. Cancer Res 2003; 63:7113-7121.

24 Buckley NE, Conlon SJ, Jirstrom K, Kay EW, Crawford NT, O'Grady A, Sheehan K, Mc Dade SS, Wang CW, McCance DJ, Johnston PG, Kennedy RD, Harkin DP, Mullan PB: The DeltaNp63 proteins are key allies of brcal in the prevention of basal-like breast cancer. Cancer Res 2011;71:1933-1944.

25 Adorno M, Cordenonsi M, Montagner M, Dupont S, Wong C, Hann B, Solari A, Bobisse S, Rondina MB, Guzzardo V, Parenti AR, Rosato A, Bicciato S, Balmain A, Piccolo S: A mutant-p53/smad complex opposes $\mathrm{p} 63$ to empower tgfbeta-induced metastasis. Cell 2009;137:87-98.

26 Carroll DK, Carroll JS, Leong CO, Cheng F, Brown M, Mills AA, Brugge JS, Ellisen LW: p63 regulates an adhesion programme and cell survival in epithelial cells. Nat Cell Biol 2006;8:551-561.

$27 \mathrm{Hu} \mathrm{M}$, Yao J, Carroll DK, Weremowicz S, Chen H, Carrasco D, Richardson A, Violette S, Nikolskaya T, Nikolsky Y, Bauerlein EL, Hahn WC, Gelman RS, Allred C, Bissell MJ, Schnitt S, Polyak K: Regulation of in situ to invasive breast carcinoma transition. Cancer Cell 2008; 13:394-406.

28 Hagiwara K, McMenamin MG, Miura K, Harris CC: Mutational analysis of the p63/ p73L/p51/p40/CUSP/KET gene in human cancer cell lines using intronic primers. Cancer Res 1999;59:4165-4169.

-29 Takeuchi Y, Tamura A, Kamiya M, Fukuda T, Ishikawa O: Immunohistochemical analyses of $\mathrm{p} 63$ expression in cutaneous tumours. Br J Dermatol 2005;153:1230-1232.

30 Quade BJ, Yang A, Wang Y, Sun D, Park J, Sheets EE, Cviko A, Federschneider JM, Peters R, McKeon FD, Crum CP: Expression of the p53 homologue p63 in early cervical neoplasia. Gynecol Oncol 2001;80:24-29.

31 Lin Z, Liu M, Li Z, Kim C, Lee E, Kim I: DeltaNp63 protein expression in uterine cervical and endometrial cancers. J Cancer Res Clin Oncol 2006;132:811-816.
32 Senoo M, Tsuchiya I, Matsumura Y, Mori T, Saito Y, Kato H, Okamoto T, Habu S: Transcriptional dysregulation of the p73L/p63/ p51/p40/KET gene in human squamous cell carcinomas: expression of Delta Np73L, a novel dominant-negative isoform, and loss of expression of the potential tumour suppressor p51. Br J Cancer 2001;84:1235-1241.

33 Bockmuhl U, Schwendel A, Dietel M, Petersen I: Distinct patterns of chromosomal alterations in high- and low-grade head and neck squamous cell carcinomas. Cancer Res 1996;56:5325-5329.

34 Bjorkqvist AM, Husgafvel-Pursiainen K, Anttila S, Karjalainen A, Tammilehto L, Mattson K, Vainio H, Knuutila S: DNA gains in $3 \mathrm{q}$ occur frequently in squamous cell carcinoma of the lung, but not in adenocarcinoma. Genes Chromosomes Cancer 1998; 22:79-82.

- 35 Choi HR, Batsakis JG, Zhan F, Sturgis E, Luna MA, El-Naggar AK: Differential expression of p53 gene family members p63 and p73 in head and neck squamous tumorigenesis. Hum Pathol 2002;33:158-164.

$36 \mathrm{Hu}$ H, Xia SH, Li AD, Xu X, Cai Y, Han YL, Wei F, Chen BS, Huang XP, Han YS, Zhang JW, Zhang X, Wu M, Wang MR: Elevated expression of $\mathrm{p} 63$ protein in human esophageal squamous cell carcinomas. Int $\mathrm{J}$ Cancer 2002;102:580-583.

37 Dellavalle RP, Walsh P, Marchbank A, Grayson TE, Su LJ, Parker ER, DeGregori J, Penheiter K, Aszterbaum M, Epstein EH Jr, Lee LA: Cusp/p63 expression in basal cell carcinoma. Exp Dermatol 2002;11:203-208.

38 Davis LD, Zhang W, Merseburger A, Young D, Xu L, Rhim JS, Moul JW, Srivastava S, Sesterhenn IA: p63 expression profile in normal and malignant prostate epithelial cells. Anticancer Res 2002;22:3819-3825.

39 Garraway LA, Lin D, Signoretti S, Waltregny D, Dilks J, Bhattacharya N, Loda M: Intermediate basal cells of the prostate: in vitro and in vivo characterization. Prostate 2003; 55:206-218.

40 Weinstein MH, Signoretti S, Loda M: Diagnostic utility of immunohistochemical staining for p63, a sensitive marker of prostatic basal cells. Mod Pathol 2002;15:13021308.

-41 Massion PP, Kuo WL, Stokoe D, Olshen AB, Treseler PA, Chin K, Chen C, Polikoff D, Jain AN, Pinkel D, Albertson DG, Jablons DM, Gray JW: Genomic copy number analysis of non-small cell lung cancer using array comparative genomic hybridization: implications of the phosphatidylinositol 3-kinase pathway. Cancer Res 2002;62: 3636-3640.

-42 Pelosi G, Pasini F, Olsen Stenholm C, Pastorino U, Maisonneuve P, Sonzogni A, Maffini F, Pruneri G, Fraggetta F, Cavallon A, Roz E, Iannucci A, Bresaola E, Viale G: p63 immunoreactivity in lung cancer: yet another player in the development of squamous cell carcinomas? J Pathol 2002;198:100-109. 
43 Wang BY, Gil J, Kaufman D, Gan L, Kohtz DS, Burstein DE: p63 in pulmonary epithelium, pulmonary squamous neoplasms, and other pulmonary tumors. Hum Pathol 2002; 33:921-926.

44 Sniezek JC, Matheny KE, Burkey BB, Netterville JL, Pietenpol JA: Expression of p63 and 14-3-3sigma in normal and hyperdifferentiated mucosa of the upper aerodigestive tract. Otolaryngol Head Neck Surg 2002;126:598601.

45 Nonaka D: A study of deltaNp63 expression in lung non-small cell carcinomas. Am J Surg Pathol 2012;36:895-899.
46 Pelosi G, Fabbri A, Bianchi F, Maisonneuve P, Rossi G, Barbareschi M, Graziano P, Cavazza A, Rekhtman N, Pastorino U, Scanagatta P, Papotti M: DeltaNp63 (p40) and thyroid transcription factor-1 immunoreactivity on small biopsies or cellblocks for typing non-small cell lung cancer: a novel two-hit, sparing-material approach. J Thorac Oncol 2012;7:281-290.

47 Bishop JA, Teruya-Feldstein J, Westra WH, Pelosi G, Travis WD, Rekhtman N: P40 (deltaNp63) is superior to $\mathrm{p} 63$ for the diagnosis of pulmonary squamous cell carcinoma. Mod Pathol 2012;25:405-415.

- 48 Uramoto H, Yamada S, Hanagiri T: Immunohistochemical staining with deltaNp63 is useful for distinguishing the squamous cell component of adenosquamous cell carcinoma of the lung. Anticancer Res 2010;30: 4717-4720.

49 Righi L, Graziano P, Fornari A, Rossi G, Barbareschi M, Cavazza A, Pelosi G, Scagliotti GV, Papotti M: Immunohistochemical subtyping of nonsmall cell lung cancer not otherwise specified in fine-needle aspiration cytology: a retrospective study of 103 cases with surgical correlation. Cancer 2011;117: 3416-3423.
50 Yoshizawa A, Motoi N, Riely GJ, Sima CS, Gerald WL, Kris MG, Park BJ, Rusch VW, Travis WD: Impact of proposed iaslc/ats/ers classification of lung adenocarcinoma: prognostic subgroups and implications for further revision of staging based on analysis of 514 stage I cases. Mod Pathol 2011;24:653664.

-51 Sica G, Yoshizawa A, Sima CS, Azzoli CG, Downey RJ, Rusch VW, Travis WD, Moreira AL: A grading system of lung adenocarcinomas based on histologic pattern is predictive of disease recurrence in stage I tumors. Am J Surg Pathol 2010;34:1155-1162. 